\title{
On the Emergence of the Technological University
}

\author{
Dr Joseph Ryan \\ Chief Executive Officer \\ Technological Higher Education Association (THEA) \\ Dublin, Ireland
}

(C) Dr Joseph Ryan. This work is licensed under the Creative Commons AttributionNonCommercial-ShareAlike 4.0 International License. To view a copy of this license, visit https://creativecommons.org/licenses/by-nc-sa/4.0/ .

It is an oft-encountered statement that the pace of change in higher education within Ireland has never been greater. Clearly such a statement cannot be true at all times, but those who voice it in the current period can do so safely without risk of contradiction. The year of 2018 has seen the passing and enactment of the Technological Universities Act which delivers the facility first documented within the National Strategy for Higher Education to 2030 which itself was published in January 2011 (Hunt, 2011). While it presages fundamental change, the Irish public would be forgiven for thinking that the gestation phase from inception to realization in respect of technological universities has been inordinately long and one can but speculate that the authors of what is referred to colloquially as the Hunt Report would not have foreseen in 2011 that the prospect proposed would have taken so long to be embraced and delivered upon. Notwithstanding, the advent of the statute has provided the prospect of the most telling change in Irish higher education for decades and one that will afford the prospective learner enhanced opportunity.

The technological university is not a novel idea. Certain neighbouring countries within the European Union have navigated a similar path and developed a dedicated sector devoted to higher professional education and training. The concept of the University of Applied Science is one that has wide recognition on the continent and is informing the policy agenda at a European level. But Ireland is singular in a number of ways; as a people, we value education greatly and for a small country we have sponsored a diversified higher education system that can respond to the differing learning styles and aptitudes of students of all ages. We also lead international tables in the large number of second level students who progress to access third level education (OECD, 2018). When they do so, they have more permeability through the system and between further and higher education than is typical of other countries; to record that fact is not to claim that the Irish system is ideal; we have further work to enhance the 
progression and complementary paths that we afford learners, but our system deserves to be acknowledged for its flexibility.

The facility to form a technological university was always elective; there was no compunction on institutes to take such a course. There were detailed and challenging criteria to meet for those electing for such a future and the first was that any such application would have to involve the merger of at least two like institutions. There was a stipulation that an institute of technology could not seek to merge with a traditional university; this was to ensure that the diversity of the system and the distinct missions of the sectors were protected. In theory, this was a simple idea; in practice, finding a complementary or contiguous partner and seeking to meld cultures is never an easy ask and considerable discussion was devoted to identifying the potential partners that eventually realized four consortia. One of the key challenges in this was to ensure that the very strong track record of the institutions and particularly in respect of the connection and commitment to their local communities was not diluted in the process of building a bigger entity. Another fear, voiced by the learners and their representatives during the consideration phase, was that the friendliness and accessibility that is a characteristic of the institutes of technology might be lost when the resulting organizations became considerably larger. Thus scale, which was proposed as a significant advantage particularly in the broader international context from such a merger, was seen by key stakeholders as a potential disadvantage. Committed staff throughout the institutions also had to be facilitated in arriving at their own determination on the balance of advantage in undertaking such significant change. In the absence of such a consensus it would be unlikely that any such proposal would win the necessary political support to advance it to a statutory footing. Enactment of the governing legislation in Spring 2018 thus marked the end of a long and complex period of consideration and negotiation and the resulting designation of the first technological university, TU Dublin, which will come into being at the start of 2019 , marks a signal moment for Irish higher education. That this will be a multicampus institution remaining strongly connected to its community and yet centred on a wonderful new open facility in the sensitively restored Grangegorman provides a concrete synthesis of the tradition and innovation that inform this exciting project. Three further consortia comprising institutes of technology in the Southeast, Southwest, and along the western seaboard are also working actively toward submission of their applications for consideration as technological universities. In addition, the remaining four institutes of technology have all continued to build capacity in line with the criteria published in relation to the achievement of technological university status. This has enhanced standards and assisted in the maintenance of sectoral cohesion while also affording their governing bodies the option of either forming or joining a technological university at some stage in the future.

In the five decades since the emergence of the Institutes of Technology in their current guise, it can be argued that they have played a pivotal role in the social cohesion and economic well-being of the country. They have also been catalysts for regional development and sustainability. Given that record of success, it is not surprising that 
questions have been raised around why one would change such a system and what precisely would distinguish a technological university from its constituent legacy institutions. There are many answers to such questions but one key focus is on the fact that higher education is necessarily in a state of constant change and that Ireland increasingly must calibrate its system to a globalized world. Increasing student mobility, advances in pedagogy, and technologically enhanced delivery modes, mean that smaller institutions will likely be less sustainable unless they are highly resourced or have a specific domain focus. Ireland has foreseen this trend and has responded with a closer alignment or incorporation of the teacher training colleges within the traditional universities along with this particular initiative, which will likely see a reduced number of institutions but of greater scale within the professional higher education space. The distinctions between a Technological University and an Institute of Technology will thus centre on scale, scope, and reach. Independent institutes of technology will continue to enhance their offerings and will remain critically connected to their regions. Having the potential to access either type of institution increases the opportunity for learners and adds to the valued diversity of the higher education system. Technological universities will remain faithful to the embrace of advanced pedagogy which will inform programmes that link to practice and which are research informed. Placement for students will characterize the whole system and the growing research profile will continue to be linked to enterprise and to the needs of the region and the state.

There are some contrary indicators currently within the Irish higher education system. Viewed from a European perspective, Ireland is admired for the numbers of students it has accessing the higher education system and for the quality of the provision. On the other hand, Irish institutions are not competing in terms of international rankings. This might invite a few reflections: first, many have pointed out that the criteria employed to determine such rankings are themselves open to question; second, given the resourcing challenges facing Irish higher education after a time of deep recession, it is actually remarkable how well the system continues to perform. But that resilience has been about survival; competing with highly resourced institutions in other advanced countries is quite another matter. This past year has seen a coordinated approach on the part of the Irish University Association along with the Technical Higher Education Association and with the full support of the Union of Students in Ireland and the teaching representative bodies, The Irish Federation of University Teachers and the Teachers Union of Ireland, in pointing towards the requirement for greater government investment in the system if we are to reach the ambition to have the finest education system in Europe by 2026 (Department of Education and Skills, 2018). The fact that progress has yet to be made on determinations and implementation arising from the expert group report on the future funding of higher education chaired by Peter Cassells points to some underlying complications and limitations in the capacity to respond (Department of Education and Skills, 2016). However, delaying decisions in 
this matter is not an option if we wish to protect our system and our international reputation.

The Technological Higher Education Association (THEA) was launched in April 2017 to be the representative and advocate for the technological sector as a whole. The initiative resulted from agreement between the Department of Education \& Skills and the 14 Institutes of Technology to realize a single body to represent the sector and one that could reflect the fact that the new statutory context would necessarily consolidate the warm and growing relationship between the 13 institutes that formed a legacy body, Institutes of Technology Ireland, and the Dublin Institute of Technology. The latter now joins with the Institute of Technology Tallaght and the Institute of Technology Blanchardstown to form the inaugural TU Dublin, which will constitute the largest third level institution in the state. This can be a pioneering institution that can set a template for the whole of our ambitious and diverse sector.

\section{References}

Department of Education and Skills (2016) Investing in National Ambition: A Strategy for Funding Higher Education. Department of Education and Skills. Available at:

https://www.education.ie/en/Publications/Policy-Reports/Investing-in-National-Ambition-AStrategy-for-Funding-Higher-Education.pdf (Accessed: 29 October 2018).

Department of Education and Skills (2018) Action Plan for Education 2018. Department of Education and Skills. Available at: https://www.education.ie/en/The-Department/Action-Planfor-Education-2016-2019/ (Accessed: 29 October 2018).

Hunt, C. (2011). National Strategy for Higher Education 2030. Higher Education Authority. Available at: http://hea.ie/resources/publications/national-strategy-for-higher-education-2030/ (Accessed: 29 October 2018).

OECD (2018) Education at a Glance 2018: OECD Indicators. OECD. Available at: https://www.oecd-ilibrary.org/education/education-at-a-glance-2018 eag-2018-en (Accessed: 29 October 2018). 